\title{
Assessing the Growth and Productivity of Rice Under Different Fertilizer Management Practices Grown Under Sri Production in Kavre, Midhill of Nepal
}

\author{
S Kandel ${ }^{1 *}$, A Shrestha ${ }^{2}$ and MP Neupane ${ }^{3}$ \\ ${ }^{1}$ Department of Agronomy, Institute of Agriculture and Animal Science, Nepal \\ ${ }^{2}$ Technical officer of Plant breeding and Genetics, NARC, Nepal \\ ${ }^{3}$ Assistant professor, Agriculture and Forestry University, Nepal \\ Submission: June 27, 2018; Published: August 29, 2018 \\ "Corresponding author: S Kandel, Department of Agronomy, Institute of Agriculture and Animal Science, Lamjung Campus, Nepal, \\ Email: smritikandel50@gmail.com
}

\begin{abstract}
A field experiment was conducted during rainy season of 2016 to evaluate the effect of different fertilizer management practices on growth and productivity of rice grown under SRI system in Kavre district at farmers' field. The experiment was laid out in Randomized Completely Block Design involving seven different fertilizer management practices viz. Nutrient Expert Rice recommended chemical fertilizer (NPK), FYM (Farm Yard Manure), TP (Titepati), SOM (Shakti organic manure), GM (Goat manure), UD (Urine Drenching) and FFP (Farmers Fertilizer Practice) with four replications. The result revealed significant difference in terms of plant height, panicle length, filled grains panicle-1, grain and straw yields and sterility\%. The highest grain yield (5.28t ha-1), straw yield (9.710t ha-1), effective tiller m-2 (210.8), panicle length $(24.23 \mathrm{~cm})$, number of filled grains panicle-1 (81.37) and the lowest sterility \% (23.82\%) were obtained from chemical fertilizer followed by Titepati, FYM, FFP, SOM, UD and the lowest grain yield (2.91t ha-1), straw yield (4.46t ha-1), effective tiller $\mathrm{m}-2$ (130.5), panicle length $(21.90 \mathrm{~cm})$ and number of filled grains panicle-1 (48.77) were obtained in goat manure and concluded that NE-Rice recommendation is the best followed by green manuring of Titepati in intensified rice production of mid-hill agro-eco zone of central Nepal.
\end{abstract}

Keywords: Growth; Productivity; Nutrient Expert Fertilizer Recommendation; SRI; Yield

Abbreviations: FYM: Farm Yard Manure, TP: Titepati; SOM: Shakti Organic Manure; GM: Goat Manure; UD: Urine Drenching; FFP: Farmers Fertilizer Practice; NPK: Ne-recommended chemical fertilizer

\section{Introduction}

Rice is one of the prominent staple cereal crops of Nepal, grown in $47.98 \%$ of the total cultivated area and shares $52 \%$ of the total food grain production which contributes around $21 \%$ to national AGDP [1]. The productivity of rice is very low i.e. 2.371t/ha (CBS, 2014/15). Among the various factors responsible for the lower production of rice, conventional farming has become one of the important one. Apart from that, use of high or low dose of fertilizer reduces yield. Thus, one of the way to increase the production is judicious application of fertilizers; balanced use of Nutrient Expert recommended dose of fertilizer will increase yield providing benefit to the farmers. "System of Rice Intensification", developed by Father Henri de Laulanie in Madagascar [2], is a new methodology for increasing the productivity of irrigated rice by changing the management of plants, soil, water and nutrients resulting in both healthy soil and plants. The present study was undertaken to assess the growth and productivity of rice under different fertilizer management practices under SRI system in Kavre/mid hill of Nepal.

\section{Materials and Methods}

A field study was conducted during rainy season in 2016 at DhitalKhola, Patlekhet, Kavre district (1000masl) in farmers' field ( $27035^{\prime} 00^{\prime \prime} \mathrm{N}$ latitude and $85040^{\prime} 00^{\prime \prime} \mathrm{E}$ longitude). The soil of experimental site was loamy with pH 5.69, OM content $1.79 \%$ and total Nitrogen content $0.09 \%$. The experiment was laid out in RCBD consisting seven fertilizer management practices viz., Nutrient Expert Rice recommended chemical fertilizer (NPK), FYM (Farm Yard Manure), TP (Titepati), (SOM) Shakti organic manure, GM (Goat manure), UD (Urine Drenching) and Farmers Fertilizer Practice (FFP) with four replications. NE recommended chemical fertilizer (NPK) was applied @ 109/2:23:46kg/ha; urea was top dressed in two split doses, FYM @10t/ha, TP @5t/ha, SOM @5t/ha, GM @5t/ha, UD @10.8t/ha and Farmers applied urea in 3 split doses @ 1.5kg N/ropani. The experimental terrace was ploughed a day before transplanting and were separated into 7 plots by bunds of 0.5 meter. Individual plot was puddled and leveled manually just before transplanting. Very young seedlings at 2 leaf stage of 15 days old was transplanted singly one plant per hill on the field with widely space $\left(25 \mathrm{~cm}^{*} 25 \mathrm{~cm}\right)$ to encourage greater root and canopy growth. Water management was done by introducing $1-2 \mathrm{~cm}$ layer of water into the paddy, followed by letting the plot dry until cracks become visible, at which time another thin layer of water is introduced. Hand weeding was done at 30DAT and 45DAT to reduce the competition between 
weeds and crops for nutrients, spaces, lights and moisture. Growth and yield characters were recorded as per standard procedures and using standard formulas.

Data entry and analysis was done using: MS excel for data input, MS word for table, IBM SPSS Statistics 21 for graphs, Gene Stat 2008 for statistical analysis. ANOVA was done at $0.05 \%$ level of significance and data were subjected to DMRT test for mean separation.

\section{Result and Discussion}

\section{Effect on yield attributes}

The result on yield attributing characters is presented in Table 1. The yield attributing characters viz. effective tillers per square meter, panicle length, filled grains per panicle, sterility percentage and test weight were highly influenced by different fertilizer management practices. The effective tillers per square meter (210.8), panicle length $(24.23 \mathrm{~cm})$, filled grains per panicle (81.37) and test weight (28.75 g) were statistically higher in chemical fertilizer treatment, whereas sterility percentage was statistically higher in urine drenching (40.70) treatment (Table 1). The highest number of effective tillers in chemical fertilizer may be due more availability of fertilizer applied in split doses. Higher filled grains per panicle in chemical fertilizer might be due to better translocation of carbohydrates, produced before heading and accumulated in leaf sheath and stem, to the panicles during grain filling. Higher sterility percentage in urine drenching treatment suggests us the poor grain filling in panicles. Similar result was also reported by various experiments carried out earlier [3-5].

Table 1: Effect of different fertilizer management on grain yield, straw yield and harvest index of rice under SRI system in Kavre/ midhill of Nepal, 2016.

\begin{tabular}{|c|c|c|c|c|c|c|c|}
\hline Treatment & $\begin{array}{c}\text { Effective till/ } \\
\mathbf{m}^{2}\end{array}$ & $\begin{array}{c}\text { Panicle } \\
\text { Length(cm) }\end{array}$ & $\begin{array}{c}\text { Filled Grains/ } \\
\text { Panicle }\end{array}$ & Sterility\% & $\begin{array}{c}\text { Test Weight } \\
\text { (g) }\end{array}$ & $\begin{array}{c}\text { Grain Yield (t/ } \\
\text { ha) }\end{array}$ & $\begin{array}{c}\text { Straw Yield (t/ } \\
\text { ha) }\end{array}$ \\
\hline $\begin{array}{c}\text { Chemical } \\
\text { fertilizer }\end{array}$ & $210.8^{\mathrm{a}}$ & $24.23^{\mathrm{a}}$ & $81.37^{\mathrm{a}}$ & $23.82^{\mathrm{b}}$ & $28.75^{\mathrm{a}}$ & $5.280^{\mathrm{a}}$ & $9.710^{\mathrm{a}}$ \\
\hline FYM & $179.0^{\mathrm{b}}$ & $23.35^{\mathrm{abc}}$ & $67.15^{\mathrm{b}}$ & $28.98^{\mathrm{b}}$ & $25.50^{\mathrm{abc}}$ & $4.410^{\mathrm{c}}$ & $7.920^{\mathrm{b}}$ \\
\hline TP & $179.6^{\mathrm{b}}$ & $23.58^{\mathrm{ab}}$ & $80.75^{\mathrm{a}}$ & $26.76^{\mathrm{b}}$ & $26.50^{\mathrm{ab}}$ & $4.870^{\mathrm{b}}$ & $8.050^{\mathrm{b}}$ \\
\hline SOM & $160.0^{\mathrm{c}}$ & $22.75^{\mathrm{abc}}$ & $53.52^{\mathrm{c}}$ & $38.88^{\mathrm{a}}$ & $21.50^{\mathrm{bc}}$ & $3.840^{\mathrm{d}}$ & $6.260^{\mathrm{d}}$ \\
\hline GM & $130.5^{\mathrm{d}}$ & $21.90^{\mathrm{c}}$ & $48.77^{\mathrm{d}}$ & $36.99^{\mathrm{a}}$ & $20.75^{\mathrm{c}}$ & $2.910^{\mathrm{e}}$ & $4.455^{\mathrm{e}}$ \\
\hline UD & $137.0^{\mathrm{d}}$ & $22.25^{\mathrm{bc}}$ & $50.20^{\mathrm{cd}}$ & $40.07^{\mathrm{a}}$ & $21.00^{\mathrm{c}}$ & $3.13^{\mathrm{e}}$ & $6.045^{\mathrm{d}}$ \\
\hline FFP & $172.0^{\mathrm{bc}}$ & $22.50^{\mathrm{bc}}$ & $64.90^{\mathrm{b}}$ & $28.65^{\mathrm{b}}$ & $24.50^{\mathrm{abc}}$ & $3.870^{\mathrm{d}}$ & $6.715 \mathrm{c}$ \\
\hline SEm \pm & 5.59 & 0.476 & 1.497 & 2.031 & 1.646 & 0.126 & 0.125 \\
\hline LSD (p=0.05) & 16.62 & 1.413 & 4.448 & 6.035 & 4.891 & 0.375 & 0.37 \\
\hline Grand Mean & 167 & 22.94 & 63.81 & 32.02 & 24.07 & 4.04 & 7.02 \\
\hline CV\% & 6.7 & 4.1 & 4.7 & 12.7 & 10.6 & 6.2 & 3.5 \\
\hline
\end{tabular}

Treatment means followed by common letters within column are not significantly different among each other based on DMRT at 0.05 .

The grain yield and straw yield of rice were also significantly influenced by the treatments as presented in Table 1; chemical fertilizer yielding higher than all other treatments. Among the organic sources, titepati yielded better over other sources where urine drenching and goat manure were poor performers in terms of grain yield. Increases in yield components are associated with better nutrition, plant growth and increased nutrient uptake [6]. Easily solubility, quick hydrolysis and rapid translocation of plant nutrients evident in the use of chemical fertilizers results in such effects while organic manures require longer period for decomposition and therefore a slow nutrient release. The improvement in yield owing to the application of chemical fertilizers might be brought by the beneficial effect of these on nutrient uptake, physiological growth [7]. Titepati and FYM which are comparatively quicker in decomposition and nutrient release seems to work better than the ones that are slowly decomposed in terms of producing rice yield.

Straw yield is a function of vegetative growth. Balanced and optimum use of fertilizer increase plant height, green leaves per hill and tillers per hill which finally resulted in higher straw yield. These results are in accordance with $[4,8,9]$. Similarly, the highest mean harvest index was observed in treatment with chemical fertilizer whereas lowest was observed in urine drenching.

\section{Conclusion}

From the trial, we got the highest yield in NE recommended chemical fertilizer whereas lowest in Goat Manure. Thus, NERice recommended fertilizer is the best followed by green manuring of Titepati in intensified rice production of mid-hill agro-ecozone of central Nepal.

\section{References}

1. Upreti HK, Khatiwada SP, Bhujel RP, Adhikari JB (2012) Evaluation of Cold Tolerant Genotypes for High Hill of Nepal. pp. 15-18.

2. Laulanie HD (2011) Intensive rice farming in Madagascar. Tropicultura 29(3): 183-187.

3. Kumar J (2006) A comparative study of Nutrient Management in Paddy under SRI and Traditional Methods of Cultivation. Msc. Thesis, Dharwad University of Agricultural Sciences, Dharwad, India.

4. Kumar R, Kumar M, Kumar A, Pandey A(2015) Productivity, profitability, nutrient uptake and soil health as influenced by establishment methods 
and nutrient management practices in transplanted rice (Oryza sativa) under hill ecosystem of North East India. Indian Journal of Agricultural Sciences 85(5): 634-639.

5. Shrestha A, Gupta G, Subedi R (2016) Evaluation of Improved Nutrient Management Practice in Yield of Rice in Jhapa District. International Journal of Research in Applied Natural and Social Sciences 4(3): 67-74.

6. Thakur RB (1993) Performance of summer rice (Oryza sativa) to varying levels of nitrogen. Indian Journal of Agronomy 38(2): 187-190.

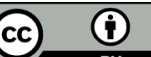

This work is licensed under Creative

Commons Attribution 4.0 License
7. Chaturvedi I (2005) Effect of nitrogen fertilizers on growth, yield and quality of hybrid rice (Oryza sativa). Journal of Central European Agriculture 6(4): 611-618

8. Rajbhandari R (2007) System of rice intensification under different plant population and levels of nitrogen. Msc Thesis, Rampur, Chitwan, India.

9. Nepal Statistical Information of Nepalese Agriculture, 2014/15.

\section{Your next submission with Juniper Publishers will reach you the below assets}

- Quality Editorial service

- Swift Peer Review

- Reprints availability

- E-prints Service

- Manuscript Podcast for convenient understanding

- Global attainment for your research

- Manuscript accessibility in different formats

( Pdf, E-pub, Full Text, Audio)

- Unceasing customer service

Track the below URL for one-step submission https://juniperpublishers.com/online-submission.php 